\title{
Investigation on thermal-hydraulic performance of outdoor heat exchanger in air sources heat pump
}

\author{
Zhaosong Fang ${ }^{\mathrm{a} b}{ }^{\mathrm{*}}$, Lafang $\mathrm{Li}^{\mathrm{c}}{ }^{\mathrm{d}}$, Yong Chen ${ }^{\mathrm{c}}$, Houhua Wang ${ }^{\mathrm{c}}$, Majeed Olaide Oladokun ${ }^{\mathrm{b}}$

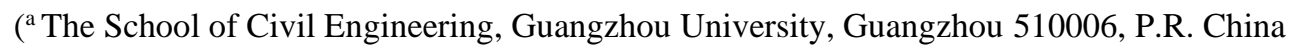 \\ ${ }^{\mathrm{b}}$ Department of Architecture and Civil Engineering, Building Energy \& Environmental Technology Research \\ Unit, Division of Building Science and Technology, City University of Hong Kong, Hong Kong \\ ${ }^{c}$ Faculty of Urban Construction and Environmental Engineering, Chongqing University, Chongqing 400045, PR \\ China \\ ${ }^{\mathrm{d}}$ Chongqing Gas Group Co.Ltd., Chongqing 400045, PR China) \\ * Corresponding author: The School of Civil Engineering, Guangzhou University, Guangzhou 510006, PR China \\ Tel.: +86 15914318669. E-mail addresses: zhaosong0102@126.com
}

\begin{abstract}
A plethora of findings exists on the decreasing heat transfer performance of ASHP under frosting condition. This study investigates, using field and laboratory experiments, the frosting behavior and heat transfer performance of fin-tube exchangers. Findings from our initial observation revealed the severity of frosting phenomenon during winter in hot summer and cold winter zone of China; for avoiding the lower COP, defrosting period of ASHP was not bigger than $60 \mathrm{~min}$. The results showed that although the basic tube surface temperature decreases with running time and remains stable after $70 \mathrm{~min}$, an adverse pressure drop ensued. The findings, thereby suggests a $70 \mathrm{~min}$ defrosting period in ASP. Comparing $j_{H} / f_{H}$ and COP between exchangers revealed an improved performance of plain fin-tube exchanger over that of louver fintube exchanger in all the test conditions. Therefore, under frosting condition, plain fin-tube heat exchanger provides a superior thermal-hydraulic performance over louver fin-tube heat exchanger. Findings from this study will help designers and facility managers in taking a more informed decision when selecting heat exchanger types for ASHP.
\end{abstract}

Keyword: heat transfer performance, fin-tube heat exchanger, comprehensive evaluation, field and experimental investigation 


\begin{tabular}{|c|c|c|c|}
\hline \multicolumn{4}{|c|}{ Nomenclature } \\
\hline ASHP & Air Source Heat Pump & $\triangle \tau$ & time interval (s) \\
\hline$Q_{w 1}$ & \multirow[b]{2}{*}{ heat transfer rate of condenser $(\mathrm{W})$} & $d_{\text {in }}$ & inlet air moisture content $(\mathrm{g} / \mathrm{kg})$ \\
\hline$Q_{w 2}$ & & $d_{\text {out }}$ & outlet air moisture content $(\mathrm{g} / \mathrm{kg})$ \\
\hline$Q_{a}$ & $\begin{array}{l}\text { heat transfer rate of fin-tube heat } \\
\text { exchanger (W) }\end{array}$ & $\mathrm{COP}$ & coefficient of performance \\
\hline$\dot{W}_{P}$ & compressor power $(\mathrm{W})$ & $\Delta \mathrm{Q}$ & energy error (W) \\
\hline$\dot{m}_{w}$ & mass flow rate of water $(\mathrm{kg} / \mathrm{s})$ & $\Delta \mathrm{P}$ & pressure drop $(\mathrm{Pa})$ \\
\hline$c$ & specific heat of water $\left(\mathrm{J} /\left(\mathrm{kg} \cdot{ }^{\circ} \mathrm{C}\right)\right)$ & $N u$ & Nusselt number \\
\hline$t_{\text {out }}$ & outlet water temperature $\left({ }^{\circ} \mathrm{C}\right)$ & $R e$ & Reynold number \\
\hline$t_{\text {in }}$ & inlet water temperature $\left({ }^{\circ} \mathrm{C}\right)$ & $\operatorname{Pr}$ & Prandtl number \\
\hline$\dot{m}_{a}$ & mass flow rate of air $(\mathrm{kg} / \mathrm{s})$ & $l$ & length of fin (m) \\
\hline$i_{\text {out }}$ & outlet enthalpy of air $(\mathrm{kJ} / \mathrm{kg})$ & $D$ & external diameter of basic tube $(\mathrm{m})$ \\
\hline$i_{\text {in }}$ & inlet enthalpy of air $(\mathrm{kJ} / \mathrm{kg})$ & $j_{H}$ & heat transfer factor \\
\hline A & surface area $\left(\mathrm{m}^{2}\right)$ & $f_{H}$ & friction factor \\
\hline$u$ & velocity $(\mathrm{m} / \mathrm{s})$ & \multicolumn{2}{|c|}{ Greek symbols } \\
\hline$L$ & length of heat exchanger (m) & $\rho$ & density of air $\left(\mathrm{kg} / \mathrm{m}^{3}\right)$ \\
\hline$W$ & width of heat exchanger (m) & $\delta$ & fin thickness (m) \\
\hline$H$ & height of heat exchanger (m) & \multicolumn{2}{|c|}{ Subscript } \\
\hline$S_{d}$ & vertical tube pitch (m) & $a$ & air \\
\hline$S$ & fin pitch (m) & $w$ & water \\
\hline$S_{h}$ & horizontal tube pitch (m) & $p$ & compressor \\
\hline$W_{f}$ & Fin width (m) & in & inlet \\
\hline$N$ & Rows' number & out & outlet \\
\hline$M_{f r}$ & accumulated mass of frost $(\mathrm{kg})$ & $f$ & fin \\
\hline
\end{tabular}

\section{Introduction}

Over the recent decades, air source heat pump (ASHP) as a renewable and sustainable energy source have been applied extensively for heating and cooling in both of commercial and residential spaces globally. However, in the winter, because of the outdoor heat exchanger surface temperature below both air dew point and freezing point of water, frost forms on the outdoor heat exchanger surfaces leading to weak heat transfer. Thus, frost remains one of the challenges in ASHP operation. The primary reason is that frosting increases the thermal resistance, but reduces the air mass flow rate. Consequently, the exchanger's heat transfer coefficient is reduced as increasing frost lowers the evaporating temperature and the refrigerating capacity. Such conditions 
have been reported to hinder the regular performance of refrigerating systems [1]. So it is important to investigate heat transfer performance of outdoor heat exchangers under frosting condition.

Presently, the louvered fin and plane tube heat exchangers are finding wider applications in ASHP due to their performance characteristics. For instance, louvered fin heat exchangers develop thin boundary layer to enhance the heat transfer performance due to interruptive surfaces that break up and reform the boundary layers under dry condition [2]. Most of the earlier studies were carried out on louvered fin heat exchangers. Wang and his research group raised experimental data for wide range of face velocities and proposed heat transfer and pressure drop correlations for different louver fin geometries and configurations [3-6]. Similarly, the study of Yan and Sheen [7] reported face velocities lower than $3.0 \mathrm{~m} / \mathrm{s}$ for louver and plain fin in typical industrial applications. Lozza and Merlo [8] compared the several fin configurations to determine the system with the best performance. Kim and Bullard [9], Kim et al. [10], Want et al. [11], Saiz Jabardo et al. [12] and Phan et al. [13] also conducted some studies on heat transfer performance of louvered-fin heat exchangers. The common conclusion amongst these earlier studies is that, although louver fin exchangers are best in thermal performance, they are characterized by higher pressure drop. With consideration for higher thermal performance over pressure drop, most heat exchangers in ASHP today, including condensers and evaporators, are made of louvered fins-tube. To this end, many other studies have been directed to enhancing the heat transfer performance of heat exchangers. An example can be seen in the studies of Ahn et al. $[14,15]$ who carried out series of experiments on the effects of nanoparticle surface deposition on heat transfer. Nonetheless, many of the performance improvement studies focused on the summer (dry) conditions. However, under winter conditions, frost layers develop on fin surface results in an increased heat transfer resistance between the fin and air, and blockage of the airflow passages through the fins [16, 17]. These reduce the coefficient of performance (COP) and, even in extreme cases, shut down the heat pump. To cater for such problems, the plain fin-tube exchangers are also popular as outdoor heat exchangers applying in ASHP under frosting condition.

In light of the application of plain fin-tube and louvered fin heat exchangers under varying weather, researchers [18-20] have examined their behavior under frosting and defrosting conditions. Xia et al. [18] studied the frosting, defrosting and re-frosting processes on louvered-fin and flat-tube heat 
exchangers and observed the variation of their heat transfer coefficients. The study concluded air pressure drop increases with defrosting cycle due to retention of condensed water droplets that subsequently re-frost. Also, the study of Yan and Li [19] compared the performance of frosted finned-tube heat exchanger with flat plain fins, one-sided louver fins, and re-direction louver fins. Findings from the study revealed that the frost formation rate and air pressure drop rate increased with increase in relative humidity or decrease in airflow rate and refrigerant temperature. Similarly, Zhang and Hrnjak [20] investigates the performance of three types of louver fin heat exchangers under frosting conditions. Their investigations revealed that round tube heat exchanger showed the longest refrigeration time due to its larger surface area. Some other researchers have equally examined the frost formation and effect of frost layer on the performance of fin-tube heat exchanger [21-26].

Many investigators have performed the studies on the thermal hydraulic performance of the plain fin-tube and louvered fin micro-channel heat exchangers [27-32], but little information exists on the study of folded louvered fin tube heat exchanger under frosting conditions. More so, nearly all the previous studies employed small-scale (laboratory) experiments coupled with a numerical method with a few study using in-situ measurement and field survey. Above all, the frosting phenomenon is seasonal as it is common during winter in hot summer and cold winter zone of China due to the weather condition. The Typical Meteorological Year (TMY) weather data [33] showed that the average outdoor temperature is $0-10{ }^{\circ} \mathrm{C}$ in the coldest month and $25-30{ }^{\circ} \mathrm{C}$ in the hottest month with relative humidity ranging between $70 \%$ and $80 \%$ (or even higher) throughout the year. In addition to these extreme weather conditions, the extended period of summer and winter (summer from early May to late September; and winter from mid-December to mid-February of the following year), underscores the need for some mechanical cooling and heating in this region. In summer, the louver fin-tube heat exchanger can perform well with enhanced heat transfer. However, in winter, the heat transfer capacity is poor. Therefore, it is imperative to investigate the heat transfer performance of the louvered fin-tube exchanger in comparison with the plain fin-tube exchanger.

This paper compares the performance of fin-tube heat exchangers by combining field survey with experimental investigations. First, using field survey, we investigate the effects of the outdoor fin- 
tube heat exchanger in ASHP in Enshi, one of the cities in hot summer and cold winter climate zone of China. Secondly, for comparison purpose, the study experimentally investigates the heat transfer performance of plain fin-tube and louver fin-tube heat exchangers. The purpose of the series of investigations is to analyze the difference in the heat transfer conditions leading to frosting in plain fin-tube heat as well as louver fin-tube heat exchanger. Findings from this study are expected to assist in decision-making on the defrost period, which remains significant for the application of fin-tube heat exchanger in ASHP in the hot summer and cold winter zone of China.

\section{Methodology}

\subsection{Field investigation}

\subsubsection{Measurement setup}

To understand frost information of ASHP in hot summer and cold winter zone of China, the field investigation is carried out in Enshi, one city of Hubei province in China. Based on the outdoor TMY weather conditions of $0.7{ }^{\circ} \mathrm{C}$ and $82 \%$ respectively for temperature and relative humidity [33], the winter ventilation design temperature is $2{ }^{\circ} \mathrm{C}$ for the case-study city. These weather conditions show the typical characteristic of hot summer and cold winter zone. In the field investigation, we selected a typical residential building with two floors. In the chosen building, we chose an air conditioned space (the living room) with $20 \mathrm{~m}^{2}$ floor area that is located on the second floor. The room is equipped with an air conditioner (model KFR-32GW/DHR (W1-H)+1) that include the outdoor heat exchanger (condenser), evaporator, and compressor. The rated parameters of this air conditioner are respectively $550 \mathrm{~m}^{3} / \mathrm{h}, 3200 \mathrm{~W}, 3520 \mathrm{~W}$, and $750 \mathrm{~W}$ for circulated air, cooling capacity, heating capacity and auxiliary heating capacity. The layout of the building is as shown in Fig. 1. 


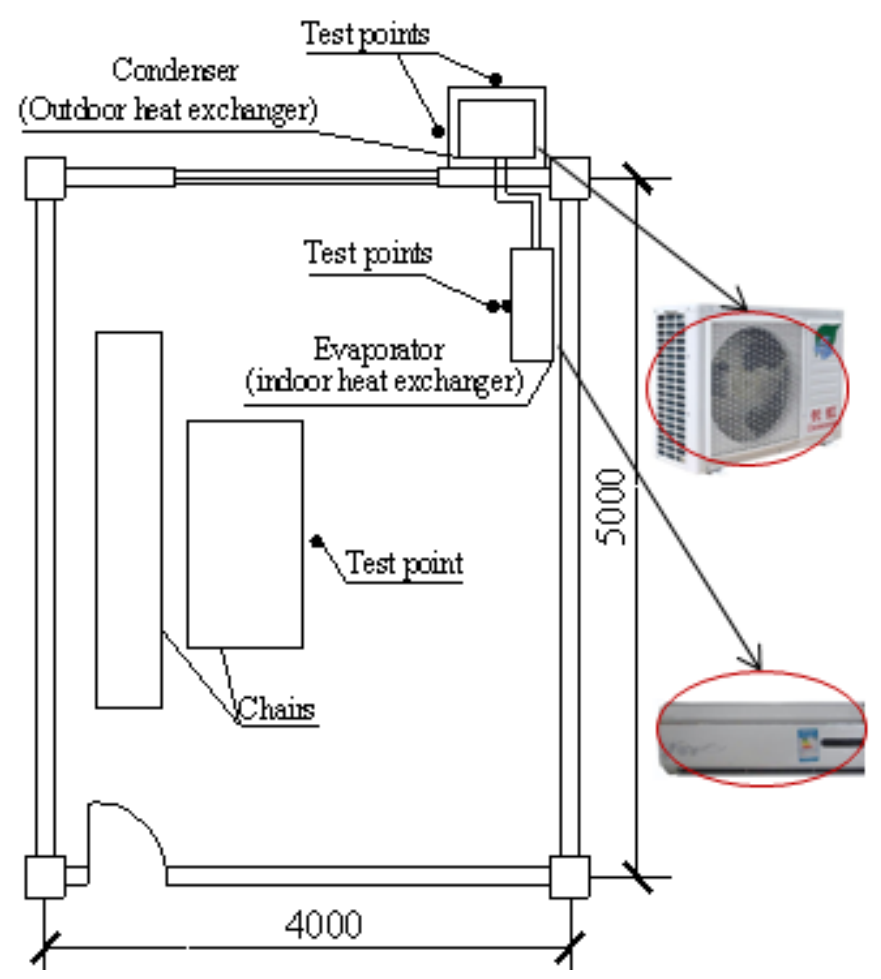

Fig. 1. The layout of the building

In the field investigation, microclimate parameters were recorded to include the outdoor air temperature and relative humidity; and indoor supply air temperature, supply relative humidity, supply air velocity, return air temperature as well as return relative humidity. Also included in the measurement is power consumption of the air conditioner. The field measurements are made of 3 sessions with each lasting 4 hours daily over a three days period.

\subsubsection{Apparatus and Process}

In this investigation, a Testo425 anemometer was used to measure the indoor air supply velocity and air temperature. The Dwyer472 digital thermocouple recorded the return air temperature. As for the indoor and outdoor air temperature and relative humidity, we employed the use of a Testo175-H1 auto-recorder as shown in Fig. 2. During the measurement, the indoor air temperature and relative humidity points were located in the middle of the room. The point of outdoor measurement is set at the location without solar radiation to eliminate the influence of direct solar radiation on the measured data. The power consumption was recorded by a universal meter 
connected to the input terminals of the air conditioner. The specifications and accuracies of all the measurement devices were as shown in Table 1.

\section{Table 1}

The detail information of the apparatus

\begin{tabular}{|c|c|c|c|}
\hline Apparatus name & Parameters & Range & Accuracies \\
\hline \multirow[t]{2}{*}{$\begin{array}{l}\text { Testo } 425 \text { thermal } \\
\text { anemometer }\end{array}$} & $\begin{array}{l}\text { Supply air } \\
\text { temperature }\end{array}$ & $-20-70{ }^{\circ} \mathrm{C}$ & $\pm 0.5^{\circ} \mathrm{C}$ \\
\hline & $\begin{array}{l}\text { Supply air } \\
\text { velocity }\end{array}$ & $\begin{array}{l}0-10 \mathrm{~m} \cdot \mathrm{s}^{-1} \text { (air temperature } \\
<20^{\circ} \mathrm{C} \text { ); } 0-20 \mathrm{~m} \cdot \mathrm{s}^{-1} \text { (air } \\
\text { temperature }>20^{\circ} \mathrm{C} \text { ) }\end{array}$ & $\begin{array}{l} \pm 5 \% \text { of measurement } \\
\text { value }\end{array}$ \\
\hline $\begin{array}{l}\text { Dwyer472 Digital } \\
\text { thermocouple }\end{array}$ & $\begin{array}{l}\text { Return air } \\
\text { temperature }\end{array}$ & $-210-1200{ }^{\circ} \mathrm{C}$ & $\pm 0.4{ }^{\circ} \mathrm{C}$ \\
\hline $\begin{array}{l}\text { testo } 175-\mathrm{H} 1 \\
\text { temperature and }\end{array}$ & $\begin{array}{l}\text { Air } \\
\text { temperature }\end{array}$ & $-20-70^{\circ} \mathrm{C}$ & $\pm 0.5^{\circ} \mathrm{C}$ \\
\hline $\begin{array}{l}\text { relative humidity } \\
\text { recorder }\end{array}$ & $\begin{array}{l}\text { Relative } \\
\text { humidity }\end{array}$ & $0-100 \% \mathrm{RH}$ & $\begin{array}{l} \pm 3 \% \text { of measurement } \\
\text { value }\end{array}$ \\
\hline $\begin{array}{l}\text { Multifunction Power } \\
\text { meter-B600Y }\end{array}$ & $\begin{array}{l}\text { Power } \\
\text { consumption }\end{array}$ & $0-100 \mathrm{~kW} / \mathrm{h}$ & $\pm 1 \%$ \\
\hline $\begin{array}{l}\text { the second standard } \\
\text { mercury thermometer }\end{array}$ & $\begin{array}{l}\text { Air } \\
\text { temperature }\end{array}$ & $-30-20{ }^{\circ} \mathrm{C}$ & $\pm 0.15^{\circ} \mathrm{C}$ \\
\hline
\end{tabular}

During the investigation, the ASHP operates in the heating mode with the air temperature setpoint at $21{ }^{\circ} \mathrm{C}$. As the air source heat pump operates, the measurement parameters were logged at a time-step of $10 \mathrm{~min}$. The data logging process lasted 4 hours. 


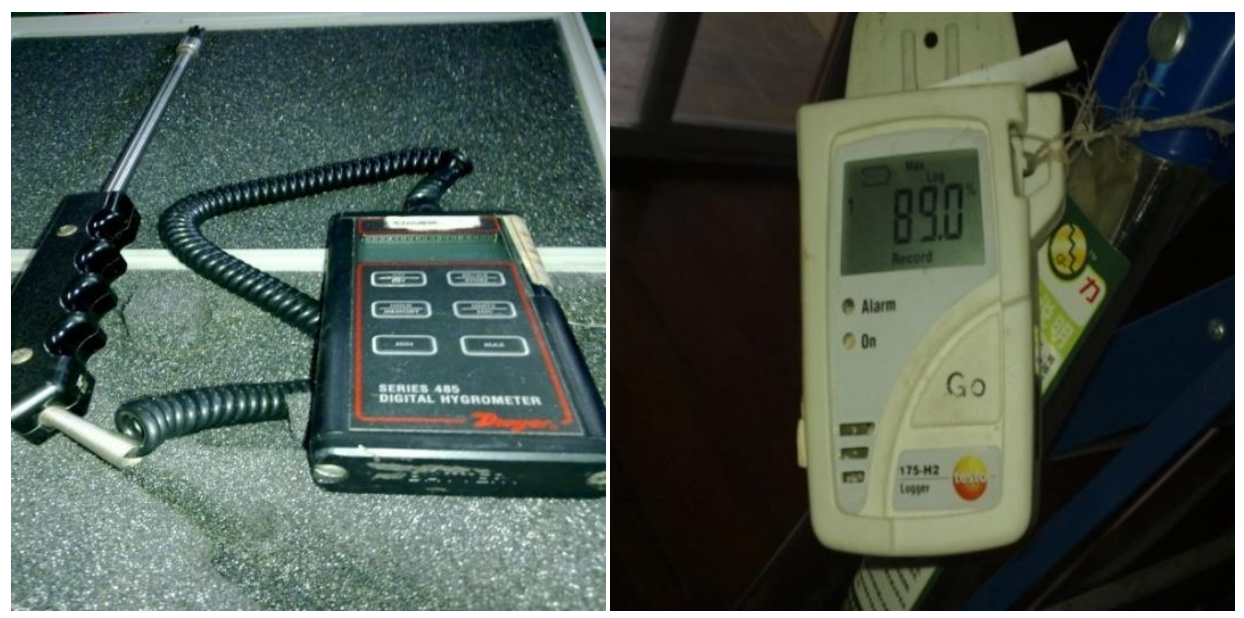

Fig. 2. Dwyer and Testo temperature and humidity recorder

\subsection{Experimental setup}

Based on the field investigation, some information on the behavior of ASHP under frosting condition can be found. However, the frost heat performance of outdoor heat exchanger could not be tested under different face velocity of heat exchanger conditions due to the effect of outdoor thermal environment and field sits. Also, although two different types of fin-tube (fin-tube and louver fin-tube) heat exchanger are generally applied in residential air conditioners, only one type of fin-tube heat exchanger was surveyed in the field investigation. Therefore, this experimental investigation is necessary to compare and analyze the heat transfer performance of both fin-tube heat exchangers under frost conditions. Regarding the field investigation, it is beneficial to decide on the experimental cases and procedures. Thus, to understand the complete frosting performance of the outdoor heat exchanger in ASHP, the experimental investigation was carried out.

\subsubsection{Test system}

Fig. 3 shows the test rig, which comprises of three parts: air flow system, refrigeration system, and measurement system. The air flow system consists of mixing chamber, measured wind tunnel, fan and valve. Controlled by the fan, the air through the inlet vises the honeycomb and current equalizer to the test part. The heat exchanger is installed in test part (300 mm $\times 300 \mathrm{~mm})$. Air is cooled in the test part, flowed into the velocity test part, and sucked by the fan thereby passes through the valve into the duct, mixing chamber and end circulating. In the duct, the heater and humidifier are installed for controlling the inlet air parameters. The refrigeration system comprises 
of the compressor, water cooled condenser, thermal expansion valve, and fin-tube heat exchanger. The air flow system and refrigeration system are insulated with polystyrene. The measurement systems are well validated for the experiments.

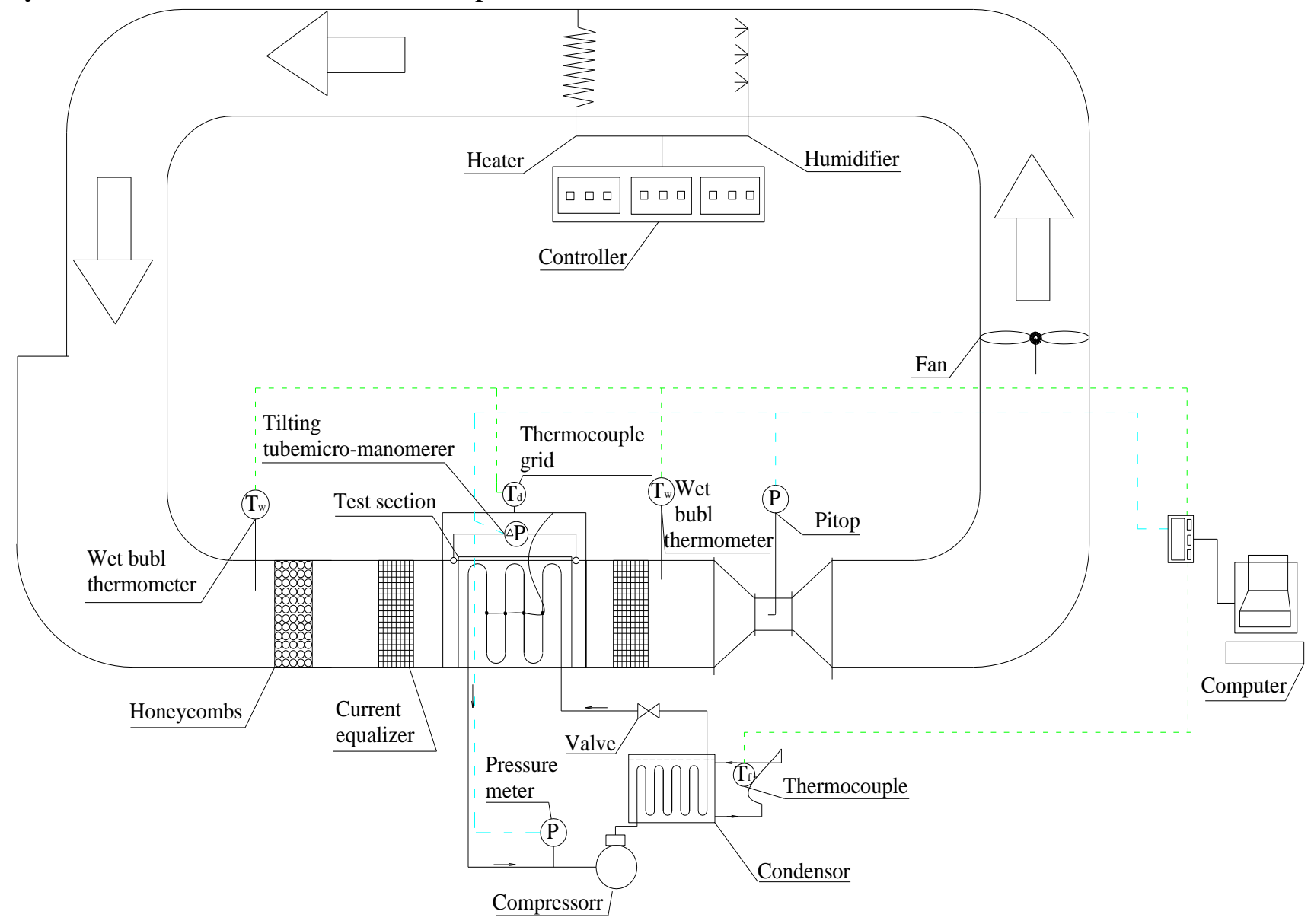

Fig. 3. Experiment equipment system

\subsubsection{Test sample}

The selected test samples were from two kinds of outdoor heat exchangers. The first was plain fintube heat exchanger while the second was louver fin-tube heat exchanger. Both of them are similar in their structural parameters but differ in shapes. Fig. 4 shows a schematic representation of the fins for both heat exchanger types. 


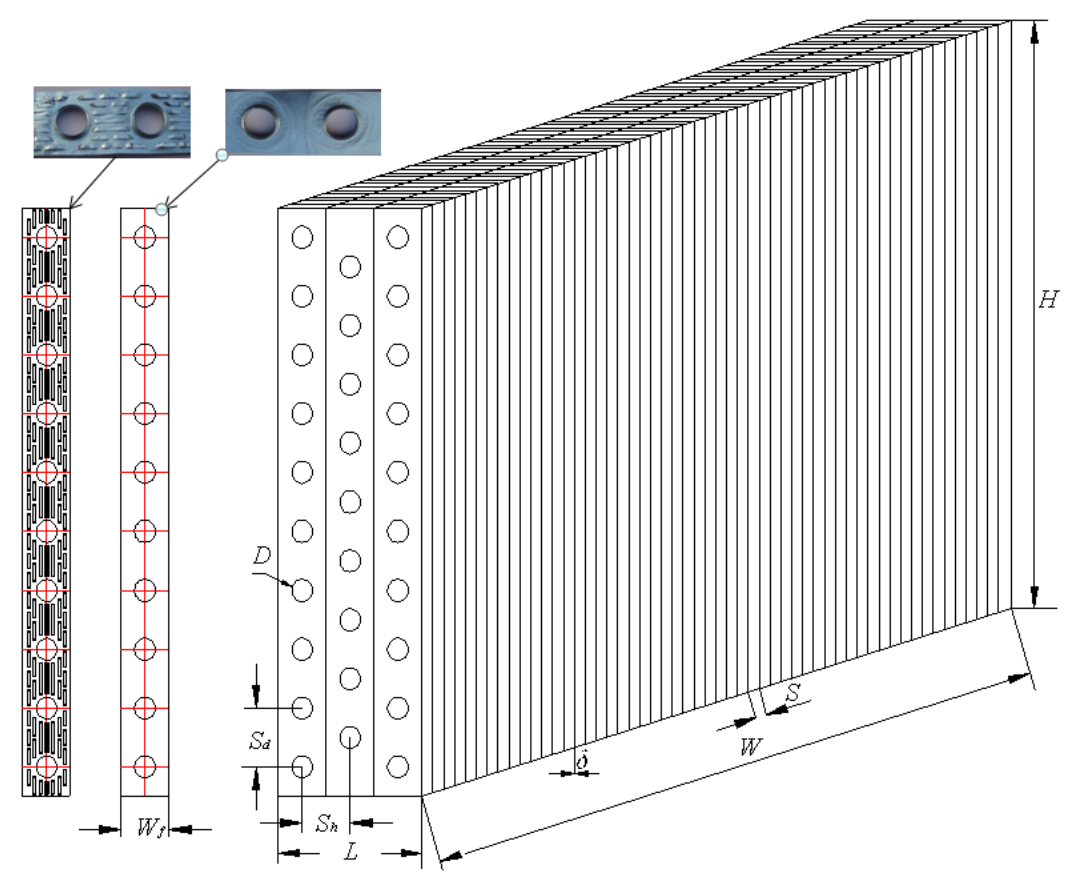

Fig. 4. The fin-tube heat exchangers

As shown in Fig. 4, both heat exchangers are made of three rows fin-tubes. Detail information of fin-tube heat exchangers is as shown in Table 2. During the experiments, the fin-tube heat exchanger samples were installed in the test part of the experimental test rig.

Table 2

Detail information of the heat exchangers

\begin{tabular}{ccccccccccc}
\hline Fin shape & $L(\mathrm{~m})$ & $W(\mathrm{~m})$ & $H(\mathrm{~m})$ & $D(\mathrm{~m})$ & $S_{d}(\mathrm{~m})$ & $S_{h}(\mathrm{~m})$ & $S(\mathrm{~m})$ & $\delta(\mathrm{m})$ & $W_{f}(\mathrm{~m})$ & $N$ \\
\hline Plain fin & 0.301 & 0.066 & 0.254 & 0.00952 & 0.0254 & 0.022 & 0.0017 & 0.00015 & 0.022 & 3 \\
Louver fin & 0.301 & 0.066 & 0.254 & 0.00952 & 0.0254 & 0.022 & 0.0017 & 0.00015 & 0.022 & 3 \\
\hline
\end{tabular}

\subsubsection{Measurement parameters and apparatus}

During the experiment, the primary measurement parameters include the pressure drop of heat exchanger, face air velocity, inlet air dry bulb and wet bulb temperature, outlet air dry bulb and wet bulb temperature, and compressor power consumption. To test the face air velocity, Pitot tube was installed in the measurement section. As for recording the heat exchanger pressure drop, the differential pressure gauge YYT - 2000 was used for both total pressure and static pressure. The 
pressure measurement range of YYT - 2000 is large at 0 - $500 \mathrm{~Pa}$. The air dry bulb temperature and basic tube surface temperature were recorded by the Agilent 349704A data acquisition instrument. All the thermocouples were calibrated for reducing the error of the measurement system. During the experiments, eight pairs of thermocouples were arranged at the inlet and an outlet for recording the air temperature. Similarly, eight pairs of thermocouples were affixed to the surface of the basic tube. The range and accuracies of apparatuses are shown in Table 1. The wet bulb temperatures were recorded by the second standard mercury thermometer. The range and accuracy of mercury thermometer are $-30-20^{\circ} \mathrm{C}, \pm 0.15^{\circ} \mathrm{C}$, respectively. The detailed information was showed in Table 1. In this experimental system, the condenser, a water-cooled type whose water was controlled by the valve.

\subsubsection{Experimental procedure}

In this investigation, heat transfer performances of the two kinds of fin-tube heat exchangers were measured under four face velocity levels $(1.35 \mathrm{~m} / \mathrm{s}, 2.00 \mathrm{~m} / \mathrm{s}, 2.73 \mathrm{~m} / \mathrm{s}$ and $3.61 \mathrm{~m} / \mathrm{s})$. During the experiments, the compressor and fan were opened at the same time. Every experimental section lasted 2 hours, and the acquisition frequency was recorded by the end of every $5 \mathrm{~min}$. To ensure the experimental accuracies, every case was performed in triplicates. As the experimental system was built in a controlled chamber, the thermal environment outside the test rig was controlled by an air conditioner to mimic the effect of outdoor thermal environment. Therefore, the initial conditions of experiments were similar to every case.

\subsection{Data processing method}

The heat transfer rate of the condenser is calculated from Eq. (1). To evaluate the energy balance in this experimental system, the heat transfer rate of the condenser is also calculated by Eq. (2). The heat transfer capacity of a fin-tube heat exchanger under frosting conditions is computed from Eq. (3). The air-side heat transfer was the sum of air-side sensible and latent heat transfer rates derived from the air temperature change and mass transfer of water vapor, respectively.

$Q_{w l}=Q_{a}+W$ 
$W_{w 2}=\dot{m}_{w} c\left(t_{\text {out }}-t_{\text {in }}\right)$

$Q_{a}=\dot{m}_{a}\left(i_{\text {out }}-i_{\text {in }}\right)$

In the Eq. (3), $\dot{m}_{a}$ is the mass flow rate of air calculated by Eq. (4)

$\dot{m}_{a}=A u \rho$

In order to evaluate the variation of the frosting mass, the frosting mass of fin-tube heat exchanger is calculated from Eq. (5). In this equation, the time step was considered. The definition of COP of the compressor is calculated from Eq. (6) as follows.

$M_{f r}=\triangle \tau \dot{m}_{a}\left(d_{\text {in }}-d_{\text {out }}\right)$

$\mathrm{COP}=\frac{Q_{a}}{W}$

Keeping the energy balance in this experimental system is crucial. Eq. (7) defines the difference between the two energy balances calculated. The difference in energy remained $\pm 5 \%$ for all tests when approaching steady conditions.

$\Delta \mathrm{Q}=\frac{2\left|Q_{w 1}-Q_{w 2}\right|}{Q_{w 1}+Q_{w 2}}$

\section{Results and discussion}

\subsection{Field measurement}

\subsubsection{Outdoor thermal environment}

The information of outdoor thermal environment is shown in Table 3. This field investigation includes 3 cases. Every case was carried out from 8:20 am to 12:20 noon every day. As shown in 
Table 3, the weather condition in the test location was characterised with light snow. The outdoor thermal environment was cold. Over the three days survey period, the average air temperatures in the test location were $2.42{ }^{\circ} \mathrm{C}, 0.56{ }^{\circ} \mathrm{C}$, and $0.16{ }^{\circ} \mathrm{C}$, respectively. Also, the relative humidity was very high, near $90 \%$ in most of the time. The characteristic of both air temperature and relative humidity in the case study reflect the weather characteristic of a typical hot summer and cold winter zone in China [34].

\section{Table 3}

The outdoor thermal parameters

\begin{tabular}{|c|c|c|c|c|c|c|c|c|c|c|}
\hline \multirow[t]{2}{*}{ Cases } & \multirow[t]{2}{*}{ Time } & \multirow[t]{2}{*}{$\begin{array}{l}\text { Weather } \\
\text { condition }\end{array}$} & \multicolumn{3}{|c|}{$\begin{array}{l}\text { Outdoor air temperature } \\
\text { (measurement) } /{ }^{\circ} \mathrm{C}\end{array}$} & \multicolumn{3}{|c|}{$\begin{array}{l}\text { Relative humidity } \\
\text { (measurement) } / \%\end{array}$} & \multicolumn{2}{|c|}{$\begin{array}{c}\text { Weather } \\
\text { report } \\
\text { temperature } \\
/{ }^{\circ} \mathrm{C}\end{array}$} \\
\hline & & & Max. & Min. & Average & Max. & Min. & Average & Max. & Min. \\
\hline 1 & $\begin{array}{l}1 / 20 / 2012 \\
8: 20-12: 20\end{array}$ & $\begin{array}{l}\text { Light to } \\
\text { moderate } \\
\text { snow }\end{array}$ & 3.31 & 1.19 & 2.42 & 93 & 86 & 89.7 & 6 & 1 \\
\hline 2 & $\begin{array}{l}1 / 21 / 2012 \\
8: 20-12: 20\end{array}$ & $\begin{array}{l}\text { light } \\
\text { snow }\end{array}$ & 1.44 & 0.13 & 0.56 & 96 & 87 & 93.6 & 4 & 0 \\
\hline 3 & $\begin{array}{l}1 / 22 / 2012 \\
8: 20-12: 20\end{array}$ & $\begin{array}{l}\text { light } \\
\text { snow to } \\
\text { cloudy }\end{array}$ & 3 & -1.88 & 0.16 & 85 & 65 & 76.1 & 3 & 0 \\
\hline
\end{tabular}

\subsubsection{Supply air temperature and heat transfer capacity}

Fig. 5 shows the variation of supply air temperature and heat transfer rate with test time. During the investigation, the air conditioner operates at the supply air temperature ranging between 36 $40{ }^{\circ} \mathrm{C}$. Comparison between three different cases revealed that some differences between the supply air temperatures. The supply air temperature of case 1 was the highest. One of the most important reasons is the outdoor air temperature was greater than that of other days. As shown in Fig. 5, there are periods with zero heat transfer rate. These points indicate the defrosting times. In cases 1 and three the defrosting times occurred at $240 \mathrm{~min}$ running time. The number of other defrosting times was 4 and 1 respectively in case 2 and 3. The frosting periods were different in 
all cases but most of them, the air condition defrosts at a period between 50 and $70 \min [26,35]$. The variation of the heat transfer rate also indicates similar results.

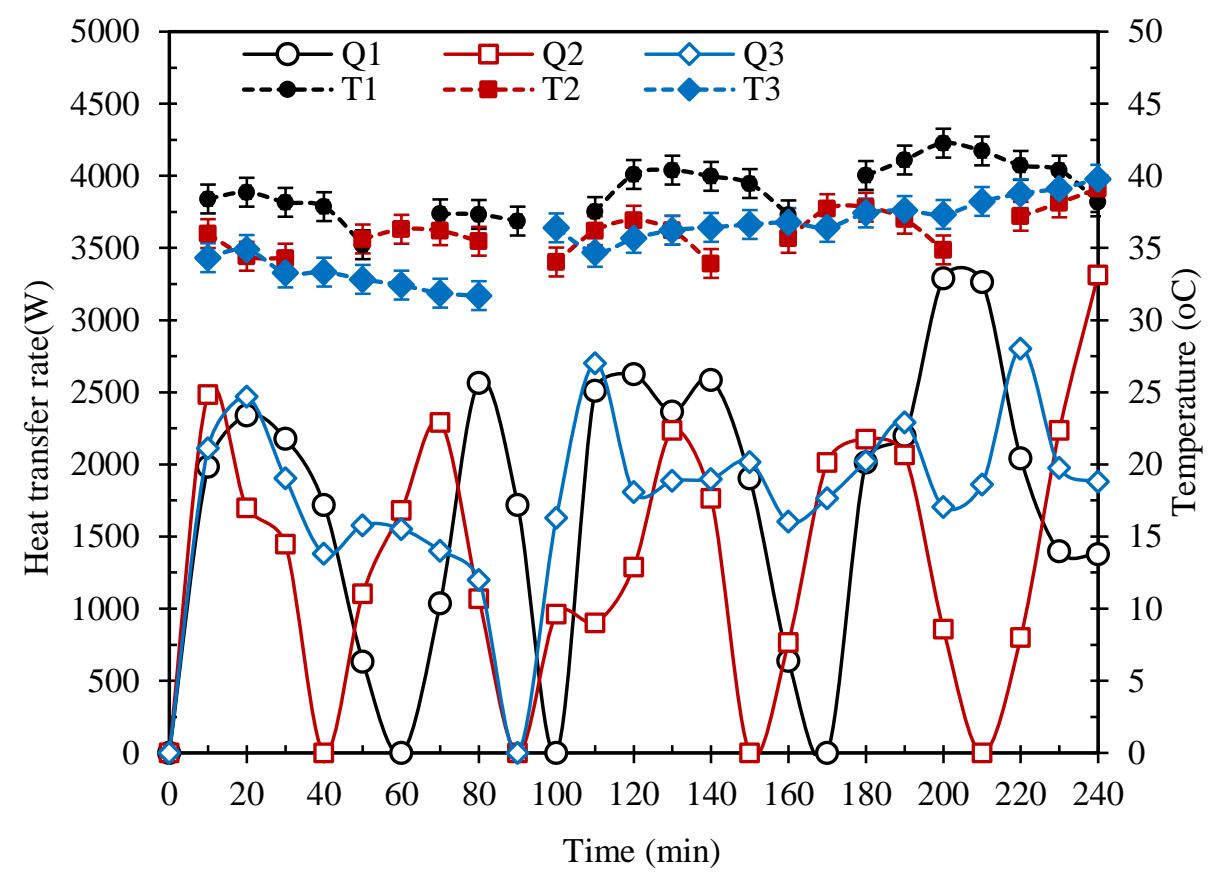

Fig. 5. Variation of the supply air temperature and heat transfer rate with test time

As shown in Fig. 5, the heat transfer rate varies with the test time. During the frosting period, the heat transfer rate sharply decreased with the running time. When the heat exchanger defrosts, the heat transfer rate equals zero. Afterward, in the initial periods following defrosting, the heat transfer quality increases and later begin to reduce with time until next defrosting. Comparing the maximum and minimum heat transfer rate, the ratio of the maximum and minimum rate is below 50\%. Therefore, when the ASHP defrosts, the heat transfer performance is feeble [36, 37]. Fig. 4 showed the growth of the frosting layer with running time in case 1, which confirms the above view. Fig. 6 shows the time evolution of frost on the ASHP fins. As would be found in the figure, when the outdoor heat exchanger runs for $50 \mathrm{~min}$, the frosting layer blocks the fin pitch thereby suggesting that it is time for defrosting. 


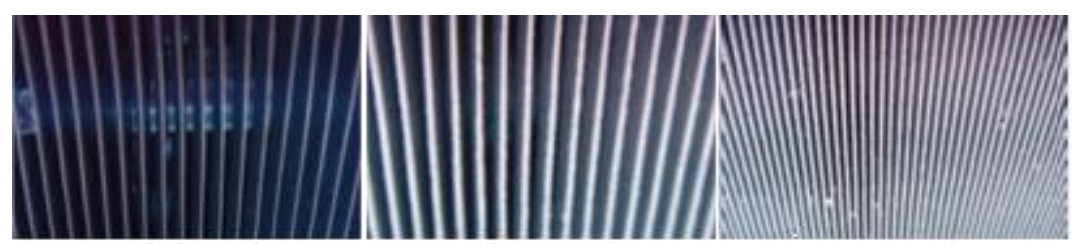

(a) $0 \mathrm{~min}$

(b) $10 \mathrm{~min}$

(c) $20 \mathrm{~min}$

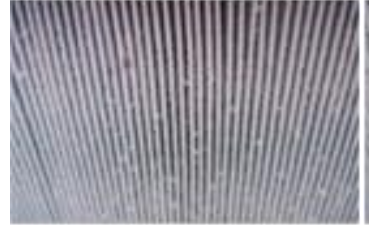

(d) $30 \mathrm{~min}$

(e) $40 \mathrm{~min}$

(f) $50 \mathrm{~min}$

Fig. 6. The variation of the growth frosting lay with the running time (case 1)

\subsubsection{Variation of coefficient of performance}

Fig. 7 shows the COP of the heat exchanger against the running time. During the frosting cycle, there are some significant differences in the experimental cases. In case 1 and 2, the maximum COP was near 2.8, but that of the case 3 was only 2.25. Before the ASHP begin to defrost, most of the COP were subtle, below 0.8. The ratio of the maximum and minimum COP was lower than 0.3. At such time, it is better to shut-down the ASHP to defrost and avoid the energy consumption at such unproductive periods. The COP of the treated cases for the whole cycle increased at first and later decrease. These findings are similar to submission from other previous studies [38, 39]. The primary reason is that the frost formed on the fin-tube exchanger increases not only thermal resistance but also lead to additional pressure drop, which reduced COP and may even, in extreme condition, result in ASHP system malfunction [40]. 


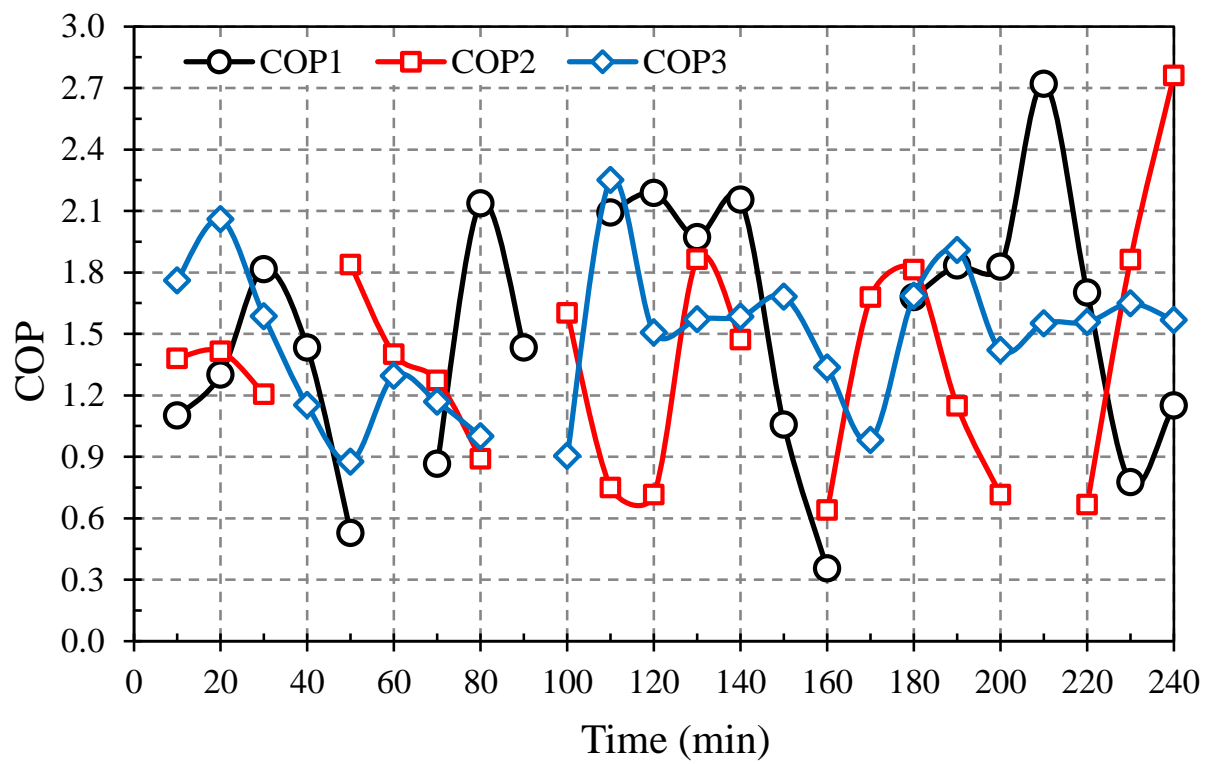

Fig. 7. The variation of coefficient of performance with running time

\subsection{Experimental investigation}

\subsubsection{Basic tube temperature and evaporation pressure of plain fin-tube exchanger}

Fig. 8 shows the variation of the tube surface temperature with time. As shown, the tube surface temperature decreased sharply in the early stage up to $11^{\circ} \mathrm{C}$ to $-12{ }^{\circ} \mathrm{C}$ in the first $30 \mathrm{~min}$. Later, the reduction in surface temperature gradually slowed down until a stable point appeared after 70 min. The surface temperatures reduced from $11^{\circ} \mathrm{C}$ to $-18{ }^{\circ} \mathrm{C}$ at the point of steady surface temperature. Equally shown in Fig. 8, it is found that irrespective of the air flow rate, the initial conditions were similar as there were petty differences among the tube surface temperatures, near $11{ }^{\circ} \mathrm{C}$. However, comparing performance at different flow rates, the tube surface temperature decrease faster in lower air flow rate than higher air flow rate. Nonetheless, the effects of variation in air flow rate diminished after $70 \mathrm{~min}$ as all of the tube surface temperatures became stable at $18{ }^{\circ} \mathrm{C}$. The primary reason for the observed variation in surface temperature is due to improved heat transfer performance at higher air flow rate than lower air flow rate, which leads to higher refrigerant temperature [41]. It should be noted that after $70 \mathrm{~min}$, the serious frosting action occurs as the heat transfer performances in all the cases were similar. Thus, the discrepancy of basic tube surface temperature was unobvious. 
Fig.9 shows the variation of the evaporation pressure. The variation was similar to the basic tube surface temperature. Near the first $30 \mathrm{~min}$, the evaporation pressures decreased sharply and then reduced more slowly. After $70 \mathrm{~min}$, the evaporation pressure was kept stable. In all the experimental processes, the evaporation pressure declined by 2.25 times from $0.36 \mathrm{MPa}$ to 0.16 $\mathrm{MPa}$ in $70 \mathrm{~min}$. The trend in the evaporation pressure of different air flow rate cases was similar.

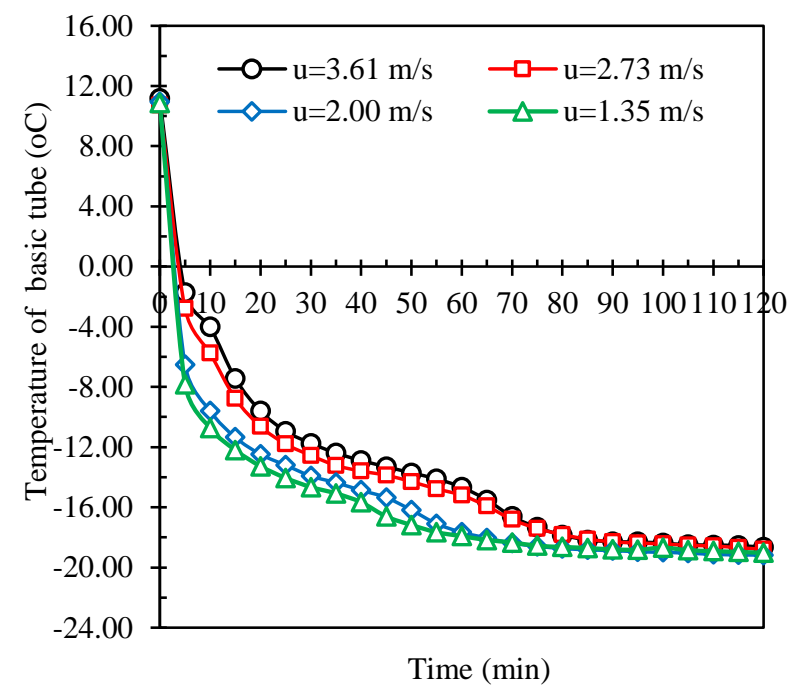

Fig. 8. Variation of basic tube surface temperature

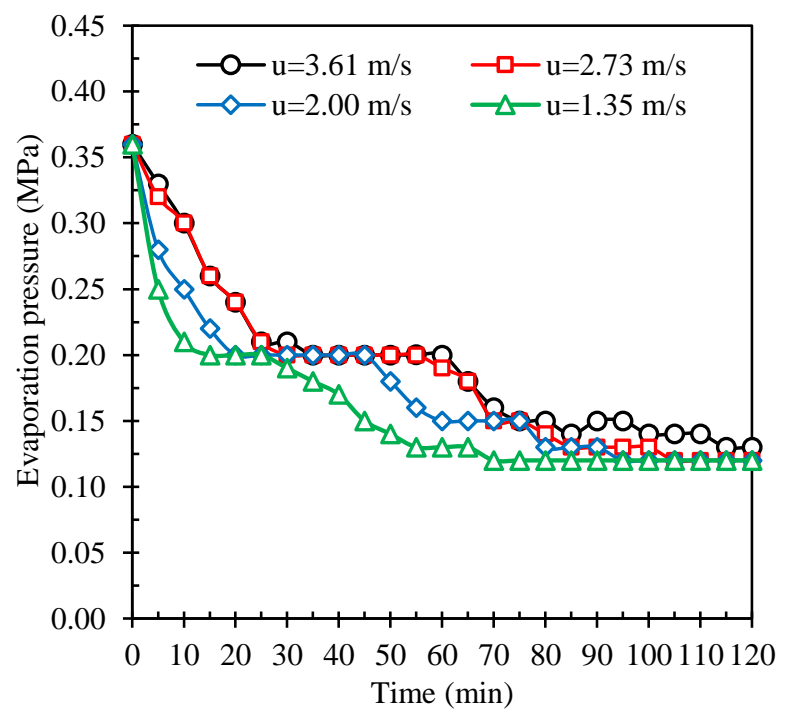

Fig. 9. Variation of Evaporation pressure

\subsubsection{Frosting capacity and pressure drop of plain fin-tube heat exchanger}

Fig. 10 shows the variation of the frosting mass. As shown in Fig. 10, the frost mass on the fintube heat exchanger increases with running time. For medium $(2.00 \mathrm{~m} / \mathrm{s}$ and $2.73 \mathrm{~m} / \mathrm{s})$ and high $(3.61 \mathrm{~m} / \mathrm{s})$ flow rates, a curvilinear relationship is observed between the frosting mass and time. This implies that at these air flow rates, the frosting mass increases with time. This continues until about 70 min when further time increment provides little contribution to frosting mass. Hence, the frosting mass growth slowed down and became relatively stable. These results are similar to the previous findings by Wang et. al [35]. Their result revealed that the frost thickness on each heat exchanger increased rapidly at the beginning. Shin et. al [42] reported that the frost thickness rapidly increased with the increase of test time with $60 \mathrm{~min}$, and then the increment slowed down. Hence, findings in the present study are in good agreement with that of the earlier documented results. As said earlier, the air flow rate has significant effects on the frosting mass. The frost mass of the higher air flow rate grew more quickly than that of lower air flow rate. In $70 \mathrm{~min}$, at the air flow rate of $3.61 \mathrm{~m} / \mathrm{s}$, the frost mass, $0.41 \mathrm{~kg}$ was 2.37 times as much as the frost mass $0.172 \mathrm{~kg}$ at 
the air flow rate of $1.35 \mathrm{~m} / \mathrm{s}$. Therefore, it can be deduced that the heat exchanger's heat transfer quality increases with air flow rate thereby result in the frost rate increase. Fig. 11 shows the time evolution of pressure drop variation at various air flow rates. In the first $20 \mathrm{~min}$, the pressure drop decreased slowly after which further increase in the running time resulted in pressure drop decreased. Upon 70 min after the experiment commenced, the pressure drop starts to be relatively stable.

Based on the above analyses of the frosting behavior and heat transfer performance of the plain fin-tube exchanger, the defrosting period should not be more than $70 \mathrm{~min}$ running time. Otherwise, the high heat transfer performance of the heat exchanger would not be guaranteed in ASHP.

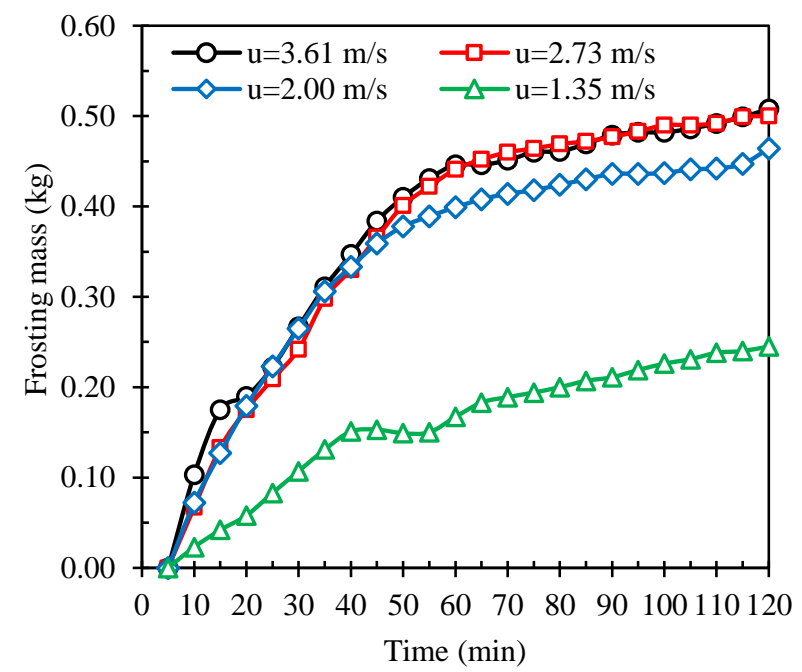

Fig. 10. variation of Frosting mass

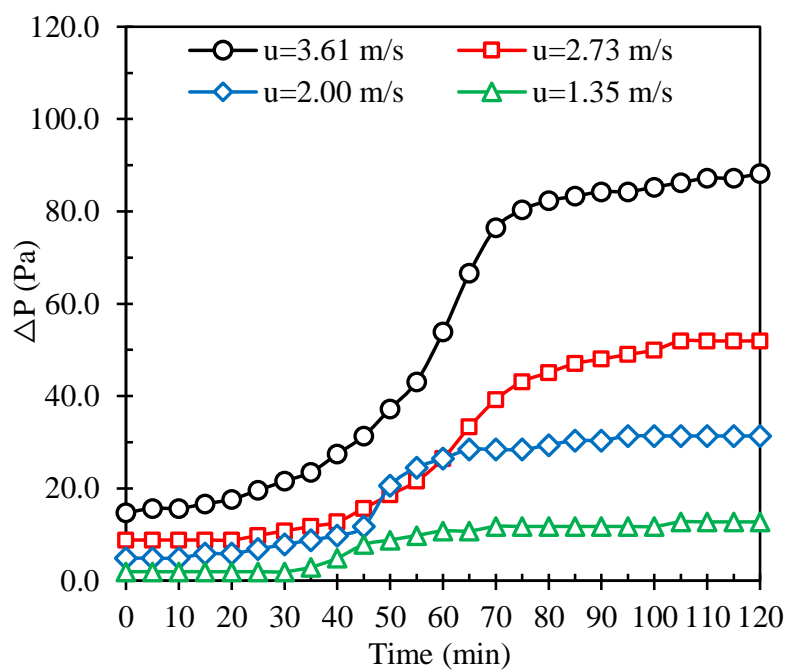

Fig. 11. Variation of pressure drop

\subsubsection{Comparing heat transfer between the plain fin-tube and louver fin- tube heat exchanger}

To compare the heat transfer performance of plain fin-tube and louver fin-tube heat exchanger, the variations of the heat transfer capacity and pressure drop of the heat exchangers were analyzed in four different air flow rates. Fig. 12 compares the heat transfer capacity of plain fin-tube and louver fin-tube heat exchangers. As shown, the heat transfer rate increases with the face air flow rate. The variation trends of heat transfers rates in both heat exchangers appears similar. However, regarding the heat transfer rates, the plain fin-tube exchanger performs better than louver fin-tube exchanger 
under the four air flow rates. The average heat transfer rate of the louver fin-tube exchanger is $15.8 \%$ lesser than that of the plain fin-tube heat exchanger. Therefore, under the frosting condition, the enhanced heat transfer effect of the louver fins type is insignificant, even weaker than the plain fin tube [35]. Under the dry condition, the louver fin can break the flow lay and reduce the heat transfer resistance, which can enhance the heat transfer. Nevertheless, under frost condition, the slot of the louver fin can be easily blocked and the fin surface covered by the frost layer [43-45], which provides the worse effect of heat transfer than plain fin exchanger.

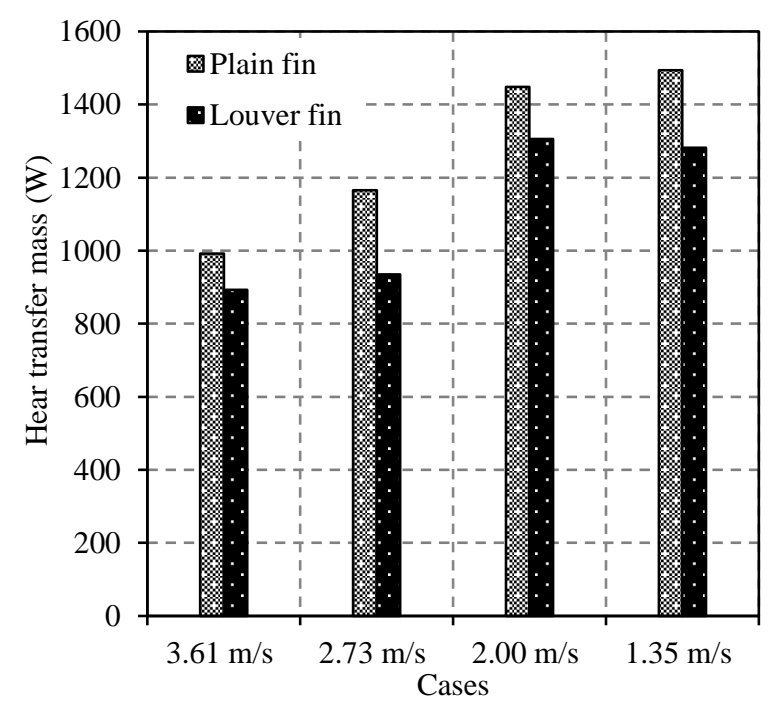

Fig. 12. Variation of Heat transfer capacity

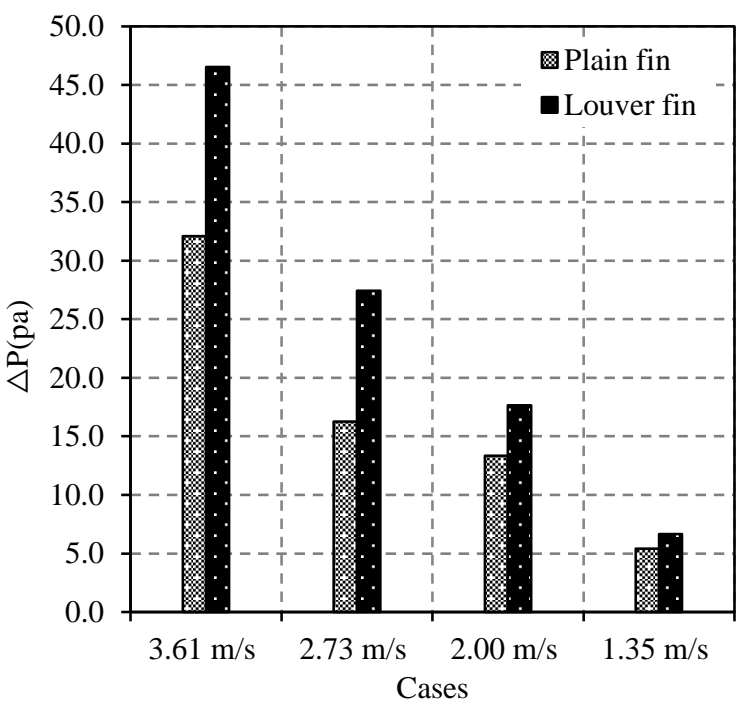

Fig. 13. Variation of Pressure drop

Pressure drop is an important index for comparing the performance of heat exchangers. Fig.13 shows the pressure drop variation of the two types of heat exchangers. The figure revealed contrary characteristics of the pressure drop variation to that of the heat transfer capacity. The pressure drop of the plain fin-tube exchanger was smaller by nearly $30 \%$ than that of louver fin-tube exchanger. Therefore, there appeared a significant difference in the frost accumulation and pressure drop between plain fin-tube and louver fin-tube exchangers. Yan and $\mathrm{Li}$ [46] found that the louver fin had larger frost accumulation amount and rapid increase in the air pressure drop than that of plain fin. Huang et. al [26], Kondepudi and O'Neal [47] also reported the same results. 


\subsubsection{Comprehensive evaluation of fin-tube exchanger}

In this experimental investigation, the heat transfer and resistance factors were applied for evaluating the heat transfer performance of the two types of fin-tube heat exchangers. We quantified the heat transfer and resistance factors from Equations (8) and (9) as follow [48]:

$j_{H}=\frac{N u}{R e \cdot \operatorname{Pr}^{1 / 3}}$

$f_{H}=\frac{2 \Delta p}{\rho u^{2} l / d}$

Fig. 14 shows the variation of $j_{H}$ for the two types fin-tube heat exchangers. From Fig. 14, it is found that the $j_{H}$ of the plain fin-tube exchanger is larger than that of louver fin-tube exchanger. The maximun $j_{H}(0.02)$ of the plain fin-tube exchanger is about 1.34 times as large as that of the louver fin-tube exchanger at an air flow rate of $1.35 \mathrm{~m} / \mathrm{s}$. For both heat echangers, $j_{H}$ descreases with air flow rate. At an air flow rate of $3.61 \mathrm{~m} / \mathrm{s}$, both heat exchangers peformed similarly in terms of their $j_{H}$ amounting to about 0.003 . As increasing air flow rates leads rapid frost layer grew, the heat resistance factor decreases with inreasing air flow rates. Hence, the findings of similar $j_{H}$ higher air flow rates supports this notion as well as proving that there is an insignificant difference in the heat resistance factor of both heat exchangers. The fins' surfaces are easily covered by the frost layer, making the fins loose the enhanced heat tranfer the effects.

Fig. 15 shows the variation of the $f_{H}$ of the two types of fin-tube heat exchangers. As shown, the variation of the $f_{H}$ is different from that of the $j_{H}$. The $f_{H}$ of plain fin-tube exchanger exceeds that of the louver fin tube exchanger. The average $f_{H}$ of the plain fin tube exchanger (0.644) is lesser by about $29.5 \%$ than that of louver fin tube exchanger (0.901). This shows that in terms of perssure drop, louver fin exchanger is worse in performance than plain fin exchanger under frosting conditions. Therefore, in order to reduce the effect of frosting, plain fin exchanger is a better choice for outdoor heat exchanger than the louver fin in ASHP. 


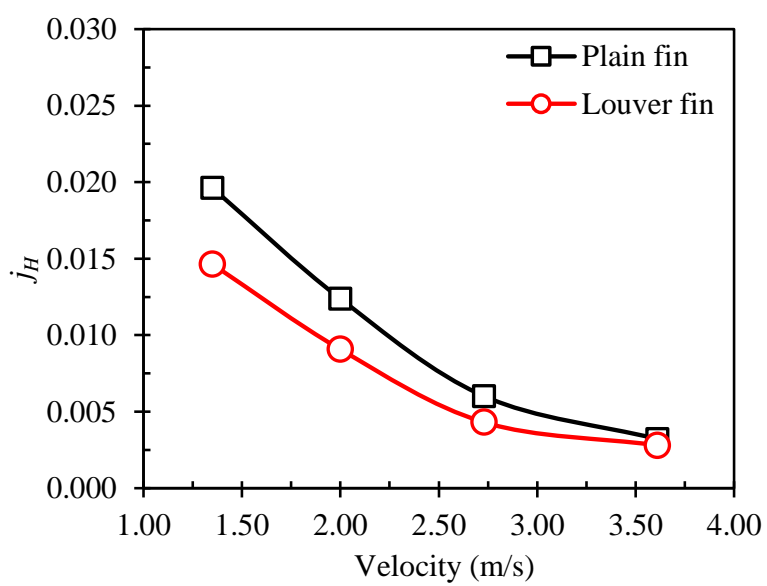

Fig. 14. variation of $j_{H}$

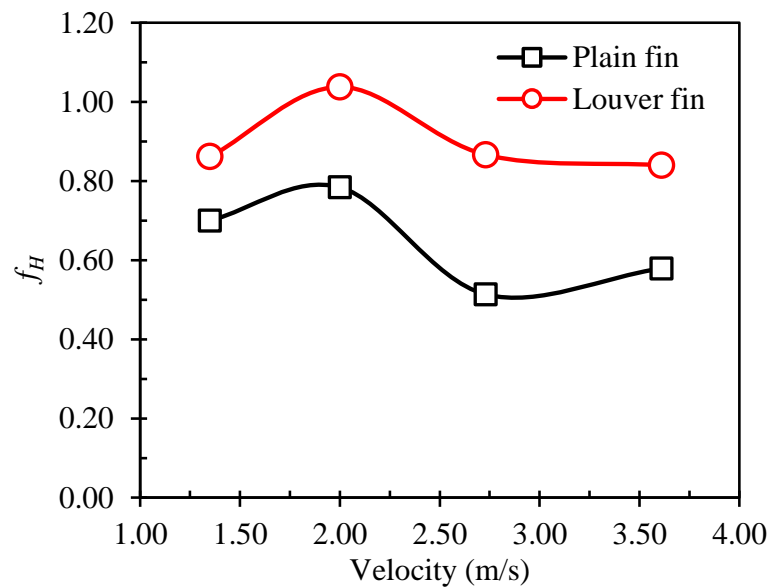

Fig. 15. Variation of $f_{H}$

Considering the effect of the heat transfer and resistance, the comprehensive evaluation index of fin-tube exchanger $j_{H} / f_{H}$ is analyzed [48]. Fig. 16 shows the variation of the $j_{H} / f_{H}$. From Fig.16, the plain fin tube exchanger performs better in $j_{H} / f_{H}$ than the louver fin tube exchanger all the treated air flow rate conditions. The variation trends in $j_{H} / f_{H}$ (Fig. 16) is simlar to $j_{H}$ plot shown in Fig. 14. At the air flow rate of $1.35 \mathrm{~m} / \mathrm{s}$, the maximum $j_{H} / f_{H}$ of plain fin tube exchanger $(0.028)$ exceeds that of that of louver fin tube exchanger $(0.017)$ by up to $65 \%$. Irrespective of this feat, with the growth of air flow rate, the advantage of the plain fin exchanger was short-lived. At the air flow rate of $3.61 \mathrm{~m} / \mathrm{s}$, the $j_{H} / f_{H}$ of plain fin tube exchanger is 0.0055 as against that of louver fin tube exchanger, which stands at 0.0033 . Therefore, in order to keep the higher heat exchanger performance, the air flow rate should be set at a lower air velocity.
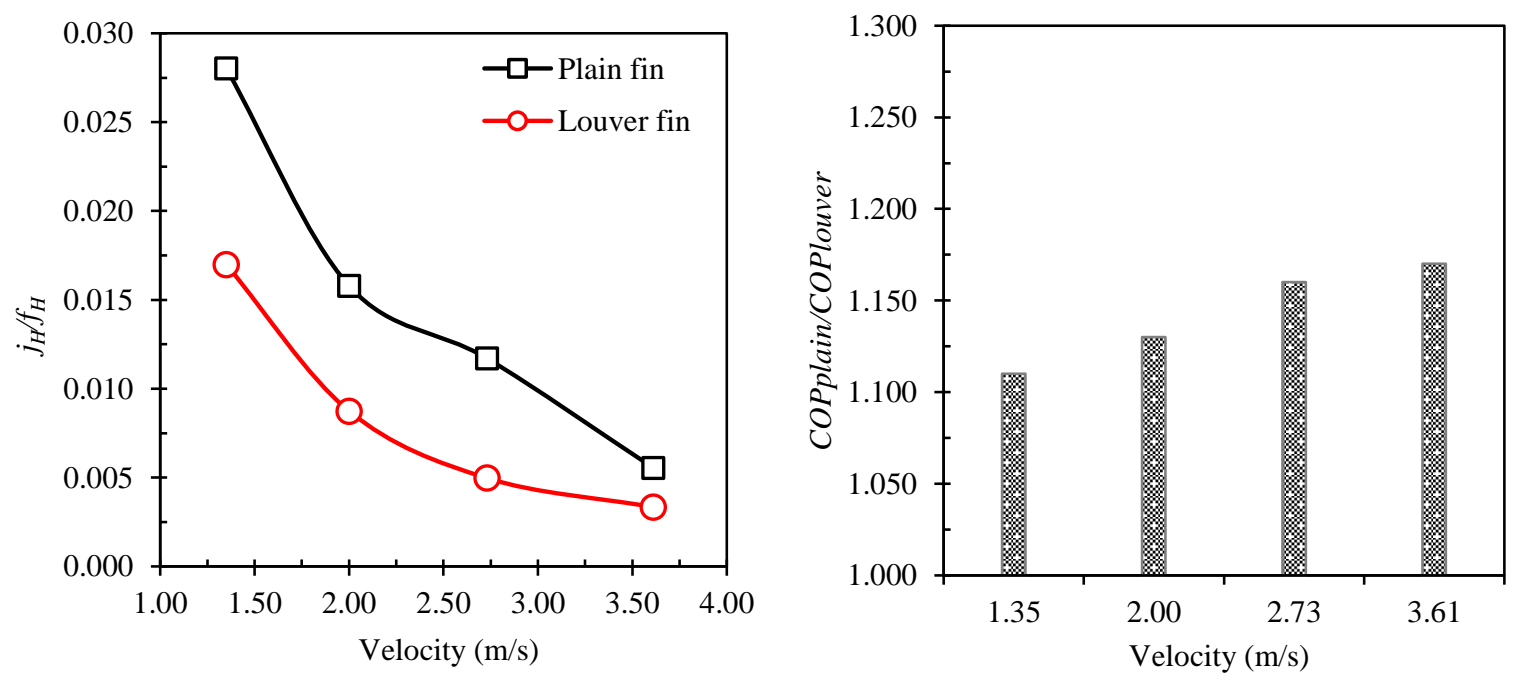
$\mathrm{COP}$ is another important index to evaluate the fin-tube exchanger. Fig. 17 shows the change of the rate of $\mathrm{COP}$ with air velocity. Comparing the $\mathrm{COP}$ of the plain fin tube exchanger with louver fin tube exchanger, the $\mathrm{COP}$ of the plain fin tube exchanger surpasses that of louver fin tube exchanger. The maximum value of COP ratio exceeded 1.15 at air flow rate of $3.61 \mathrm{~m} / \mathrm{s}$. In all the treated air flow rates, the COP ratios were higher than 1.1. This suggests that during the running time, the heat transfer performance of plain fin tube exchanger is better than that of louver fin tube exchanger. Accordingly, similar to the corresponding characteristic of the $j_{H} / f_{H}$, the comprehesive heat transfer performance of plain fin tube exchanger is advantageous than louver fin tube exchanger in ASHP under frosting condition.

\section{Conclusion}

In this paper, the field investigation on the frosting phenomenon was carried out to examine the heat transfer performance of ASHP in one of the typical cities, Enshi, a hot summer and cold winter zone of China. The results showed that the frosting phenomenon is serious in winter in hot summer and cold winter zone of China. The defrosting period of ASHP is irregular but most of the defrosting period is around $60 \mathrm{~min}$. The COP of the ASHP was found to operate below 0.8. In order to analyze the heat transfer performance of fin tube heat exchanger, one experimental facility was designed and built to investigate the thermo-hydraulic performance of fin tube heat exchangers. The experiments were carried out with two different types of fin-tube heat exchangers, including plain fin tube heat exchanger and louver fin tube heat exchanger, at four different air flow rates. The basic tube surface temperature decreased with the running time and then kept relatively stable at a certain level after $70 \mathrm{~min}$. However, the trend of variation of pressure drop was adverse to that of basic tube surface temperature. The pressure drop increased dramatically with the running time. Until $70 \mathrm{~min}$, the pressure drop was kept near constant. Based on the findings about the thermohydraulic performance variation with running time, the defrosting period should be less than 70 $\min$.

The comprehensive evaluation indices, including $j_{H}, f_{H}, j_{H} / f_{H}$ and ratio of COP, were applied to compare the thermal-hydraulic performance of plain and louver fin tube heat exchangers. It was 
found that $j_{H} / f_{H}$ of the plain fin tube exchanger is better than that of louver fin tube exchanger in every air flow rate condition. The maximum was 0.028 , by 1.65 times, more than that of louver fin tube exchanger 0.017. The COP of the plain fin tube exchanger is bigger than that of louver fin tube exchanger. The maximum of the ratio was bigger than the 1.15. In all the different air flow rate cases, the ratios of $\mathrm{COP}$ are higher than 1.1. Therefore, under frosting condition, the thermalhydraulic performance of plain fin tube heat exchanger is better than that of louver fin tube heat exchanger. In hot summer and cold winter climate zones of china, the outdoor heat exchanger made of plain fin-tube can provide better heat transfer performance than the louver fin tube in winter. Findings from this study will be of help to designers and specifiers of ASHP for not only the test location but other locations with similar weather conditions.

\section{Acknowledgements}

This work is supported by the Major project of Ministry of Science and Technology of Guangdong Province, No. 2012A010800019.

\section{Reference}

[1]. H. Qin, W. Li, B. Dong, Z. Zhao, W. Zhu, Experimental study of the characteristic of frosting on low-temperature air cooler, Experimental Thermal and Fluid Science, 55 (2014) $106-114$

[2]. J.S. Park, D.R. Kim, K.S. Lee, Local frost behaviors of a scaled-up louvered fin heat exchanger, International Journal of Heat and Mass Transfer, 89 (2015) 1127-1134.

[3]. C.C. Wang and K.Y. Chi, Heat transfer and friction characteristics of plain fin-and-tube heat exchangers, Part I: new experimental data, International Journal of Heat and Mass Transfer, 43 (2000) 2681-2691.

[4]. C.C. Wang, K.Y. Chi, Y.J. Chang, P.Y. Chang, An experimental study of heat transfer and friction characteristics of typical louver fin-and-tube heat exchangers, International Journal of Heat and Mass Transfer, 41 (1998) 817-822.

[5]. C.C. Wang, C.J. Lee, C.T. Chang, S.P. Lin, Heat transfer and friction correlation for compact louvered fin-and-tube heat exchangers, International Journal of Heat and Mass Transfer, 42 (1999) 1945-1956. 
[6]. C.C. Wang, Y.M. Tsai, D.C. Lu, Comprehensive study of convex louver and wavy finand-tube heat exchangers, Journal of Thermo-physics and Heat Transfer, 12 (3) (1998) 423-430.

[7]. W.M. Yan and P.J. Sheen, Heat transfer and friction characteristics of fin-and-tube heat exchangers, International Journal of Heat and Mass Transfer, 43 (2000) 1651-1659.

[8]. G. Lozza and U. Merlo, An experimental investigation of heat transfer and friction losses of interrupted and wavy fins for fin-and-tube heat exchangers, International Journal of Refrigeration, 24 (2001) 409-416.

[9]. M.H. Kim, and C.W. Bullard, Air-side performance of brazed aluminum heat exchangers under dehumidifying conditions. International Journal of Refrigeration, 25 (5) (2002) 641652.

[10]. M. H. Kim, J.M. Yin, C.W. Bullard, P.S. Hrnjak, Development of a micro-channel evaporator model for a $\mathrm{CO}_{2}$ mobile air-conditioner. In: Proceedings of the ASME, Advanced Energy Systems Division, 40 (2000) 47-54.

[11]. C.C. Wang, Y.T. Lin, C.J. Lee, Heat and momentum transfer for compact louvered finand-tube heat exchangers in wet conditions, International Journal of Heat and Mass Transfer, 43 (18) (2000) 3443-3452.

[12]. J.M.S. Jabardo, J.R.B.Z. Filho, A. Salamanca, Experimental study of the air side performance of louver and wave fin-and-tube coils, Experimental Thermal and Fluid Science, 30 (7) (2006) 621-631.

[13]. T.L. Phan, K.S. Chang, Y.C. Kwon, J.T. Kwon, Experimental study on heat and mass transfer characteristics of louvered fin-tube heat exchangers under wet condition, International Communications in Heat and Mass Transfer, 38 (7) (2011) 893-899.

[14]. H.S. Ahn, S. H. Kang, M. H. Kim, Visualized effect of alumina nanoparticles surface deposition on water flow boiling heat transfer, Experimental Thermal and Fluid Science, 37 (2012) 154-163

[15]. H.S. Ahn, S.H. Kang, H. Jo, H. Kim, M.H. Kim, Visualization study of the effects of nanoparticles surface deposition on convective flow boiling CHF from a short heated wall, International Journal of Multiphase Flow 37 (2011) 215-228. 
[16]. J. Dong, Y. Jiang, Y. Yao, X. Zhang, Operating performance of novel reverse-cycle defrosting method based on thermal energy storage for air source heat pump, Journal of Central South University of Technology, 18 (6) (2011) 2163-2169.

[17]. A.H. Fard, Z. Aidoun, M. Ouzzane, Applying refrigerant mixtures with thermal glide in cold climate air-source heat pumps, Applied Thermal Engineering, 62 (2) (2014) 714-722.

[18]. Y. Xia, Y. Zhong, P.S. Hrnjak, A.M. Jacobi, Frost, defrost, and re-frost and its impact on the air-side thermal-hydraulic performance of louvered-fin, flat-tube heat exchangers, International Journal of Refrigeration, 29 (2006) 1066-1079.

[19]. W. Yan, H. Li, Y.L. Tsay, Thermal fluid characteristics of frosted finned-tube heat exchanger, International Journal of Heat and Mass Transfer, 48 (2005) 3073-3080.

[20]. P. Zhang and P.S. Hrnjak, Air-side performance evaluation of three types of heat exchangers in dry, wet and periodic frosting conditions, International Journal of Refrigeration, 32 (2009) 911-921.

[21]. X. Guo, Y. Chen, W. Wang, C. Chen, Experimental study on frost growth and dynamic performance of air source heat pump system, Applied Thermal Engineering, 28 (17) (2008) 2267-2278.

[22]. K. Lenic, A. Trp, B. Frankovic, Transient two-dimensional model of frost formation on a fin-and-tube heat exchanger, International Journal of Heat and Mass Transfer, 52 (1) (2009) 22-32.

[23]. J. Cui, W. Li, Y. Liu, Y. Zhao, A new model for predicting performance of fin-and-tube heat exchanger under frost condition, International Journal of Heat Fluid Flow, 32 (1) (2011) 249-260.

[24]. K. Kim, K.S. Lee, Frosting and defrosting characteristics of surface-treated louvered-fin heat exchangers: effects of fin pitch and experimental conditions, International Journal of Heat and Mass Transfer, 60 (2013) 505-511.

[25]. M. Lee, Y. Kim, H. Lee, Y. Kim, Air-side heat transfer characteristics of flat plate finnedtube heat exchangers with large fin pitches under frosting conditions, International Journal of Heat and Mass Transfer, 53 (13) (2010) 2655-2661.

[26]. D. Huang, Z. Jing, Y. Liu, D. Yi, Effect of fin types of outdoor fan-supplied finned-tube heat exchanger on periodic frosting and defrosting performance of a residential air-source heat pump, Applied Thermal Engineering, 69 (1) (2014) 251-260. 
[27]. Y. Xia and A.M. Jacobi, A model for predicting the thermal-hydraulic performance of louvered-fin, flat-tube heat exchangers under frosting conditions, International journal of refrigeration, 33 (2010) 321-333.

[28]. K. Kim, M.H. Kim, D. R. Kim, K.S. Lee, Thermal performance of microchannel heat exchangers according to the design parameters under the frosting conditions, International Journal of Heat and Mass Transfer, 71 (2014) 626-632.

[29]. B. Xu, Q. Han, J. Chen, Feng Li, N. Wang, D. Li, X. Pan, Experimental investigation of frost and defrost performance of micro-channel heat exchangers for heat pump systems, Applied Energy, 103 (2013) 180-188.

[30]. B. Xu, C. Zhang, Y. Wang, J. Chen, K. Xu, F. Li, N. Wang, Experimental investigation of the performance of micro-channel heat exchangers with a new type of fin under wet and frosting conditions, Applied Thermal Engineering, 89 (2015) 444-458.

[31]. H. Moallem, S.r Padhmanabhan, L. Cremaschi, D. E. Fisher, Experimental investigation of the surface temperature and water retention effects on the frosting performance of a compact micro-channel heat exchanger for heat pump systems, International journal of refrigeration, 35 (2012) 171-186.

[32]. E. Moallem, L. Cremaschi, D.E. Fisher, S. Padhmanabhan, Experimental measurements of the surface coating and water retention effects on frosting performance of micro-channel heat exchangers for heat pump systems, Experimental Thermal and Fluid Science, 39 (2012) 176-188.

[33]. Meteorological information center of China meteorological administration and Tsinghua University, Special meteorological data set for building thermal environment in China. China Architecture and Building Press, Beijing, 2005.

[34]. Q. Zhang and H. Yang, Typical meteorological parameters handbook for buildings, China Architecture \& Building Press, 2012.

[35]. F. Wang, C. Liang, M. Yang, C. Fan, X. Zhang, Effects of surface characteristic on frosting and defrosting behaviors of fin-tube heat exchangers, Applied Thermal Engineering, 75 (2015) 1126-1132.

[36]. Z. Fang, H. Wang, J. Zhang, W. Wu, Experimental analysis on frosting characteristic of SK-type finned refrigerating heat exchanger with large-diameter circular holes, Applied Thermal Engineering, 64 (2014) 192-200. 
[37]. M.H. Kim, H. Kim, D.R. Kim, K.S. Lee, A novel louvered fin design to enhance thermal and drainage performances during periodic frosting/defrosting conditions, Energy Conversion and Management, 110 (2016) 494-500.

[38]. A.F. Emery and B.L. Siegel, Experimental measurements of the effects of frost formation on heat exchanger performance, Proceedings of AIAA/ASME Thermo physics and Heat Transfer Conference, 139 (1990) 1-7.

[39]. Y. Jiang, H. Fu, Y. Yao, L. Yan, Q. Gao, Experimental study on concentration change of spray solution used for a novel non-frosting air source heat pump system, Energy and Buildings, 68 (2014) 707-712.

[40]. L. Huang, Z. Liu, Y. Liu, Y. Gou, J. Wang, Experimental study on frost release on fin-andtube heat exchangers by use of a novel anti-frosting paint, Experimental Thermal and Fluid Science, 33 (2009) 1049-1054.

[41]. Q. Yan, Refrigeration technology and application, China Architecture \& Building Press, 2006.

[42]. J. Shin, A.V. Tikhonov, C. Kim, Experimental study on frost structure on surfaces with different hydrophilicity: density and thermal conductivity, Journal of Heat Transfer, 125 (1) (2003) 84-94.

[43]. D. L. da Silva, C.J.L. Hermes, C. Melo, Experimental study of frost accumulation on fansupplied tube-fin evaporators, Applied Thermal Engineering, 31 (2011) 1013-1020.

[44]. K. Kim and K.S. Lee, Characteristics and performance evaluation of surface-treated louvered-fin heat exchangers under frosting and wet conditions, International Journal of Heat and Mass Transfer, 55 (2012) 6676-6681.

[45]. K. Kim and K.S. Lee, Frosting and defrosting characteristics of surface-treated louveredfin heat exchangers: Effects of fin pitch and experimental conditions, International Journal of Heat and Mass Transfer, 60 (2013) 505-511.

[46]. W. Yan, H. Li, Y.L. Tsay, Thermo-fluid characteristics of frosted finned-tube heat exchanger, International Journal of Heat and Mass Transfer, 48 (2005) 3073-3080.

[47]. S.N. Kondepudi and D.L. O'Neal, The effects of different fin configurations on the performance of finned-tube heat exchangers under frosting conditions, ASHRAE Trans, 96 (2) (1990) 439-444 


\section{Experimental Thermal and Fluid Science}

Volume 84, June 2017, Pages 28-38

[48]. W. Li, W. Tao, H. Kang, H. Li, R. Xin, Experimental study on heat transfer and pressure drop characteristic for fin-and-tube heat exchangers, Journal of Mechanical Engineering, 1(1997) 81-86 